\title{
The Electronic State: Estonia's New Media Revolution
}

\author{
Alec Charles
}

\begin{abstract}
This article examines the case of Estonia as one of Europe's fastest growing informational economies, and asks whether its furious development of new media technologies, as industrial products, commercial resources and political instruments, has necessarily proven as beneficial to society at large as some domestic and international commentators have anticipated. After mapping Estonia's unique development in embracing new technologies since the mid-1990s, the article concludes with a study of Estonia's recent experiments in electronic voting: in 2007, Estonia was lauded as the first country in the world to afford voters at national parliamentary elections the opportunity to vote online from their homes. The article is based on a series of interviews conducted by the author with a number of prominent figures in Estonia's IT industry, private and voluntary sectors, government service and politics. It addresses issues arising out of academic literature relating to the ethical, social and political aspects of the proliferation of new media, within the context of related surveys and reports produced by governmental and transnational organisations.
\end{abstract}

IN A PAPER ENTITLED ‘E-DEMOCRACY - WHAT IS THE BIG IDEA?', STEPHEN COLEMAN (2005a: 6) cites an Estonian government website as a practical use of the Internet to foster democratic participation. Pratchett (2007: 10) similarly cites Estonian examples of "major e-democracy initiatives". Much has been made of Estonia's leap into the electronic age, perhaps because its rapid and massive adoption of new media technologies may be seen as affording a bridge from its past as a minor republic of the Soviet Union, annexed by Stalin in 1940, towards its current condition as an independent democracy based on the principles of market economics, a member of NATO and of the European Union. In many ways Estonia represents an admirable model of the development of liberal democratic nationhood in the wake of political oppression and a command economy.

There is a romantic heroism vivid within the prevalent narrative of Estonian history. It is a country which, after centuries of domination by greater powers in north-eastern Europe - Denmark, Sweden, Germany and Russia - first declared independence in 1918 , only to be swallowed up by the Soviet Union 22 years later, and to remain part of that empire for more than half a century. This romantic portrait of its history tends to ignore, for example, the complicity of its partisan movement in the early 1940 s with the forces of the Third Reich. It also sidelines the more problematic aspects of Estonian nationalism which continue to this day, most clearly and controversially in the country's response to its minority Russian-speaking population.

Thanks are due to all of the participants in this study and to the University of Bedfordshire's Research Institute for Media, Art \& Design (and in particular to Institute Director Professor Alexis Weedon) for supporting this research.

ISSN 1815-347X online. Charles, A. (2009). 'The Electronic State: Estonia's New Media Revolution', Journal of Contemporary European Research, Vol. 5, No. 1, pp. 97-113. Available: http://www.jcer.net/ojs.index.php/jcer/article/view/122/127 
Since the mid-1990s new technologies have undoubtedly sponsored the internationalisation of Estonia, in terms of its economic, industrial, cultural and educational development. Its middle classes have enthusiastically adopted the systems and perspectives of western capitalism, and the majority of its population has benefited, materially, socially and politically, from these new structures. The prevalent assumption, however, that new media technologies have at the same time directly underpinned the country's processes of democratisation (in terms, for example, of electronic governance and online voting) is rather more open to question. Indeed this article suggests that the uses of such technologies may in fact undermine Estonia's democratic development, in that they may simultaneously reinforce commercial and political structures and entrenched socio-ethnic divisions.

This article is based upon an empirical study undertaken between 2004 and 2007. It is specifically grounded upon a series of interviews conducted by the author during that period with a number of interviewees generally recognised as key players in Estonia's development of both private and public sector electronic services. ${ }^{1}$ The article does not draw sharp distinctions between these areas of private and public sector electronic service provision, insofar as the modern Estonian state itself, founded upon postCommunist, centre right principles of society and governance, tends fundamentally to blur such distinctions. Estonian civil society is a mode of corporate society: the nation's prioritisation of the private-public partnership model is so deeply embedded that (to a western European observer) its refusal to separate commercial interests from public responsibilities may appear at the very least to foster an ambiguity of accountability, or indeed to prove detrimental to the processes of progressive liberal democracy.

This study has therefore sought opinion from figures in Estonia's banking industry (a national and international pioneer of the digital service model), its Information Technology (IT) industry (not only an area of great economic significance to the country, but also one which has, as a result, proven hugely influential upon government policies on public service provision and consultation platforms), its voluntary and charitable sector (prominent players in this anti-interventionist market economy's model of public service provision), its private-public partnership organisations (in the areas of electronic public service provision), its civil service (including key government advisers on the provision of electronic services) and its political elite (including the Minister of Social Affairs in office at the time of Estonia's first trial of electronic voting for parliamentary elections). ${ }^{2}$ These interview subjects were selected on the advice of Estonian academic and media experts as key players in the field. ${ }^{3}$

\footnotetext{
${ }^{1}$ A total of 14 interviews were conducted for this study. Participants were asked for information on the development of Estonia's electronic provision of commercial and governmental services, and for their opinions on the success and future of this provision, in open and free-ranging discussions of the subject. Participants were asked questions relating to their particular areas of expertise, competence and responsibility. The majority of interviews were conducted in person, but a number were conducted by telephone or e-mail (with follow-ups where necessary) where that was most convenient for the participants. As these interviews represent expert testimony rather than general survey data, their findings should not be considered in terms of statistical significance.

2 The study comprised interviews with six representatives of the commercial sector, four representatives of the public sector, two representatives of the voluntary sector and two well-known journalists in the field.

${ }^{3}$ Participants included the (then) Minister of Social Affairs, the (then)Communications Adviser to the Prime Minister, the Prime Minister's former adviser on electronic development (now Associate Professor at the Estonian IT College), the former head of the country's Data Communication Department (now Chief Operating Officer of the country's electronic certification agency), the Marketing Manager of the country's electronic certification agency, the heads of two of Estonia's largest software development companies, the head of the country's largest IT company, the Head of IT and the EU \& Structural Funds Manager at Estonia's largest bank, and the heads of the country's two most significant voluntary sector organisations for the dissemination of electronic provision (wifi.ee) and education (Look@World).
} 
This article is also informed by the four years (2001-2005) during which the author held a professorship in media studies at Audentes University (now part of Tallinn University of Technology) in Estonia. Its argument and tone reflect a mixture of enthusiasm and scepticism towards the electronic provision of public sector services displayed by prominent members of the country's academic, journalistic, political and diplomatic communities: some of whom have been identified within this study, some of whom have preferred to keep their opinions off the record.

This article compares and contrasts this empirical evidence with the findings of a number of journalistic, academic, governmental and international accounts of this process, and suggests that, beneath the hype and the sincere excitement, a set of significant problems and contradictions may be discovered.

\section{Terminology: e-service, e-government, e-democracy}

The availability of the electronic provision of commercial services (in, for example, the financial industry or the information supply sector) is virtually ubiquitous in the industrialised world, and the replication of this model in the public sector (in the form, for example, of online tax returns, direct debit digital payments for state services and the electronic dissemination of public service information) is similarly common. As Coleman (2005c: 207) suggests, "shopping, banking, learning, travel and health care are being reshaped by new forms of mediation, so it seems unlikely that political representation could remain undisturbed." Thus the commercial e-service model transfers into the area of e-government. The successful adoption of this paradigm by political parties (such as by Barack Obama on his journey to the White House) is one manifestation of this phenomenon. Yet the Obama model (whose success in U.S. voter engagement eclipsed Howard Dean's more limited use of online communication technologies in his bid for the 2004 Democratic Presidential nomination) involved not only online fund-raising and campaigning activities, but also the possibility (or at least the appearance) of participation in policy debates on, for instance, the candidate's Facebook site. A number of governments have made similar use of (or claims for) the Internet as a site for democratic participation. Thus, electronic politics and electronic government have argued for their potential to move beyond the commercial sales and supply model towards a two-way or dialogical paradigm. E-government therefore announces the possibility of something more than e-services; it (not unattractively) offers the chance of e-democracy - of interactive popular participation in political processes: "interactivity opens up unprecedented opportunities for more inclusive engagement in the deliberation of policy issues" (Coleman 2005c: 209). This is a vision in which, as Coleman and Spiller (2003: 11-12) propose, "interactive technologies, which can facilitate online consultation and dialogue, make direct representation a possibility."

But this is only the beginning. If democracy's ultimate expression and test take place at the ballot box, then electronic democracy may be seen as coming of age in the introduction of online voting. Stephen Coleman (2005b: 97) writes that "online voting may be conducted via regulated computers in conventional polling stations, but its most ambitious use is as a means of remote voting, allowing voters to participate in elections wherever they have access to an Internet connection."

Risks of course accrue to this process. Coleman (2005b: 96) pertinently enquires as to the nature of these risks: "Are risks purely technological or are there other processes at stake?" As he goes on to suggest, these risks (which technologists may see merely in terms of systems security) may become matters of moral security - when for example, "citizens who do not have... Internet access might regard online voting as an act of discrimination" (Coleman 2005b: 99). For the most part this paper addresses issues of moral security: other studies (most notably the work of OSCE and of Estonia's National Electoral Committee, both of which have proven highly valuable for this study) more 
closely examine - and for the most part legitimise - the technological security aspects of Estonia's pioneering efforts in online voting.

This paper presents one specific case study in an attempt to examine those moral risks, and to investigate the possible benefits for whose sake those risks might be incurred. Those perceived or projected advantages tend to be based upon ambitions of increased civil and democratic participation. Thus Xenakis and Macintosh (2007: 14) write:

Usually, the prospective benefits from the introduction of e-voting technologies are related to the hypothesis that the convenience offered can be used as a counterbalance against voter apathy and therefore increase voter turnout, which in turn legitimises the outcome of the electoral process.

However, as those authors go on to stress, this hypothesis remains unproven.

\title{
The Reinforcement Hypothesis
}

The ethical, educational, social and political ramifications of the sudden proliferation of new information and communication technologies have in recent years become a matter of increasing concern to scholars working in the fields of computing, sociology, media studies and politics. In their study of Computer Ethics and Professional Responsibility, Bynum and Rogerson (2004b: 318) address the crucial question as to whether "the Internet [will] foster global democracy? Or will it become a tool for control and manipulation of the masses by a handful of powerful governments?" Bynum and Rogerson (2004a: 6) describe a contemporary scenario in which academic opinion on these questions is polarized between cyberoptimism and cyberpessimism:

\begin{abstract}
Optimists point out that information technology, appropriately used, can enable better citizen participation in democratic processes, can make government more open and accountable, can provide easy citizen access to government information, reports, services, plans, and proposed legislation. Pessimists, on the other hand, worry that government officials who are regularly bombarded with emails from angry voters might easily be swayed by short-term swings in public mood... that dictatorial governments might find ways to use computer technology to control and intimidate the population more effectively than ever before.
\end{abstract}

The risks of electronic governance may often appear clearer than the benefits. As Gibson et al. (2004: 8) suggest, "whether e-government or e-service provision has much to do with participation or democracy is... questionable." Indeed, as Nixon (2007: 29) points out, "a range of studies shows that the number of e-government projects that can be considered as total or partial failures ranges... from 60 to 85 per cent of all projects." More problematic, however, than the mere failures of new technologies to foster civil society and democratic participation are suggestions that these systems may in fact undermine opportunities for popular representation.

As well as increasing public access to information, new media technologies may, for example, allow governments and economic interests greater powers to disseminate and legitimise their own agendas. As Catherine Needham (2004: 65) notes, "direct consultation of citizens can be a resource for the executive branch of government, used to sideline the representative claims of the legislature by giving the executive an independent channel to public opinion." This situation leads the growing ranks of cyberpessimists towards what has been dubbed the reinforcement hypothesis. This theory is neatly summarized by Raab and Bellamy (2004: 21) when they argue that "technology becomes a tool for the reinforcement of existing power structures." 


\section{The Digital Divide}

The uneven distribution of these crucial tools of access to intellectual and cultural capital is a problem not only for an electronic society as a whole; it is also a specifically critical issue for the practices of online government. Indeed, in 2003 the United Nations' World Public Sector Report (2003: 6) warned that broad sections of national populations were not necessarily reaping the benefits of state investments in electronic governance.

Manuel Castells (1996) has predicted that, although the proportion of the world's population with access to the Internet will increase to 30 per cent by 2010 , half of those still unconnected by that date will never once in their lives even have used a telephone. Writing shortly before 9/11, Robert Kaplan (2001) prophetically added that the economic divisions resulting from these knowledge gaps would promote forms of violent resistance which would themselves be able to take advantage of the very technologies whose inequitable distribution prompted those material inequalities.

Thus Neumann (2004: 208) pertinently asks whether we are "creating a bipolar society of computer-literate insiders and everyone else? Or a multipolar society of various distinct categories? Are we disenfranchising any sectors of society, such as ordinary mortals and people who do not have computer resources?" According to Margolis (2007: 2), the electronic gap comes to reflect the socio-economic, educational and demographic divides of the non-virtual world: "we have witnessed a normalisation of the politics of cyberspace, the emergence of a political and economic order that largely replicates that found in the physical world."

Nixon and Kontrakou (2007: xxi) report that "citizens of lower educational attainment [are] less likely to be online." This not only leads to a reinforcement of social, economic and educational schisms forged along demographic lines, but may also imply a set of specific and acute risks incurred by the adoption of new communication technologies for the purposes of political, parliamentary and governmental information, consultation and representation. As Nicholas Pleace (2007: 69) points out, "poor Internet access remains strongly associated with households with low incomes, the very people with whom e-government needs to engage... The implications for electronic voting are obvious. The poorer parts of the population are less likely to vote." It may therefore appear inevitable that, as Åström (2004: 107) suggests, "Internet voting... shifts the bias toward the middle and upper classes: the already politically active."

In an interview with Chris Middleton (1999), Simon Rogerson proposed that "the concept of online government implies literacy, and an awareness and acceptance of technology. That isn't the case in practice. The ethical principles of education and awareness should be introduced to recognise this." In this context, it seems worthwhile to examine the case of Estonia, a small, modernizing and relatively new country which has become well-known for its rapid developments in the IT sector and specifically in the area of electronic governance.

\section{The Case of Estonia}

Perched on the north-eastern edge of Europe, and wedged in between Finland, Russia and Latvia, the Baltic republic of Estonia achieved independence from the Soviet Union in 1991, and joined the European Union on 1 May 2004.

Estonia has a population of about 1.3 million people. According to the Organisation for Security and Co-operation in Europe (OSCE 2007: 10) Estonia's population includes 125,799 people who are officially stateless. The vast majority of these non-citizens are ethnic Russians. Despite OSCE's recommendations that Estonia "facilitate citizenship" 
(OSCE 2007: 1) for this sector of the populace, progress remains painfully (one suspects, grudgingly) slow: indeed, the Estonian government itself has recently admitted the failure of its own Population Ministry's ethnic minority integration policies (TubalkainTrell 2008). This disenfranchised minority represents the most extreme example of the massive disparity between Estonia's socially, economically, educationally and politically privileged and disadvantaged classes. Estonia has one of the European Union's largest gaps between the rich and the poor, and that divide appears to be increasing.

In 2004 the Heritage Foundation ranked Estonia as the world's fourth most successful nation in the fostering of economic freedoms. It should be stressed that the Heritage Foundation tends to define its notion of economic freedom in terms of the freedoms of owners and employers, rather than those of employees or citizens - or, indeed, of the unemployed or the stateless. The laissez-faire economic policies adopted by successive governments elected since Estonia regained its independence (policies such as the diminution of corporate taxation and the rejection of progressive income tax) have enriched particular geographical, social and industrial sectors. In particular, the capital city of Tallinn (with a population of 430,000 people) has developed a booming middle class and IT sector. Estonia's wealth remains concentrated around the area of Tallinn, in the north-west of the country. Questions remain as to how - and whether - this newfound prosperity can be harnessed to improve the lives of the general population. Indeed, Mikecz (2005: 153-154) writes that: "north-western Estonia, which is home to 38 per cent of the country's population and 44 per cent of its labour force... has attracted over 88 per cent of foreign capital... Estonia has the highest levels of income inequality in the EU... 18 per cent of the population has a disposable income less than 60 per cent of the national median income."

Towards the end of 2007 Estonia was ranked by the Foreign Policy Globalisation Index as the world's tenth most globalised nation (Collier 2007). A crucial factor in this ranking was the country's assimilation of new information and communication technologies. Estonia is therefore a key case in the debate as to whether new media are likely to improve the lives and rights of entire populations, rather than merely of their more privileged sections - not only because of the country's current uneven distribution of economic opportunities and social and intellectual resources, but also because of the fact that Estonia has, for the last decade, attempted to position itself as a society at the cutting edge of contemporary information technologies: 'E-stonia' - as it has liked to fashion itself. As this paper will argue, the undoubted economic benefits achieved by Estonia's enthusiasm for electronic commerce and the IT industry may not be mirrored by the more problematic consequences of its ongoing experiments in the areas of electronic government and e-democracy.

\section{E-conomy}

In 1997 Estonia launched the 'Tiger Leap Initiative', ${ }^{4}$ an ambitious and remarkably successful economic, technological and educational programme designed to establish Estonia as a modern and competitive e-state. Even before this initiative, Estonia's financial industry had started to exploit new technologies. The world's first online banking services started in 1995. By the end of 1996, there were only about 20 such services worldwide - and three of them were Estonian.

In 2003 a World Economic Forum Report ranked Estonia in eighth position (out of 82 countries) for its methods of putting the Internet to practical use. It came in at number three for e-government, and at number two for Internet banking. The number of Estonians who choose to bank online has risen to more than 700,000 - more than half the total population. The government is also encouraging the online provision of other

4 The Estonian Tiger Leap into the 21st Century. Available at:
http://www.esis.ee/ist2000/background/tiigrihype/contents.html, last accessed 6th April 2009 
financial services: in 2003, more than 130,000 Estonians chose to file their tax returns over the Internet. ${ }^{5}$

The country's largest financial services provider, Hansabank, also encompasses the largest IT organisation in the country. The head of the bank's IT department, Olari llison, has argued that his country has moved "from the Stone Age to the IT Age. Western banks are struggling with old systems which are difficult to upgrade and adapt to Internet banking, but we leapfrogged the mainframe era" (interview, July 2004). The bank's EU and Structural Funds Manager, Aivar Roop, has added that Hansabank has "contributed revolutionary inputs to the whole banking business in Europe, including e-banking" (interview, April 2005).

The nation's size has worked to its advantage in terms of the adoption and development of information technologies. Peter Priisalm, CEO of Estonia's largest specialist IT company, MicroLink, points out that "as Estonia is a small country, it's much easier for its local companies and organisations to change their IT systems than it is for older multinational organisations" (interview, April 2004). This relationship between the size of the country and its speed and flexibility of development was emphasised in 2004 by the (then) Minister of Foreign Affairs, Kristiina Ojuland, in an interview with the International Herald Tribune: "Estonia is a small country. You can do things in a small country fast if you have political will" (Fuller 2004).

Estonia's IT progress has been boosted by the involvement of local companies in the development of such high-profile software projects as the web-based telephone system Skype and the file-sharing application Kazaa. The Estonian company that designed FastTrack, the technology behind Kazaa, is called Bluemoon Interactive. The company's founder Jaan Tallinn is restricted by his transnational parent company from direct comment on the development or sale of this software, but the corporation was kind enough to permit mediated access. Tallinn commented: "Kazaa came to us with an opportunity to provide a technical solution to their idea. With our background in producing video games, it was a challenge that we gladly took on" (interview, April 2004).

Another Estonian IT company, Curonia Research, has pioneered a medical system called Doc@Home which allows the user to collect their medical data at home and send it via the Internet to their doctor. The company received a million euros in funding from the European Commission, and has run pilot projects in Britain, Germany, Finland and Estonia. The main function of Doc@Home is to prevent the need for hospitalisation. However, the CEO of Curonia Research, Ardo Reinsalu, has admitted that, although his company may see the profits, his country is unlikely to witness the social benefits. Reinsalu comments: "Estonia is definitely not our target market. A day in hospital costs 20 euros in Estonia. That same day could cost $£ 2,000$ in the UK. The savings on hospital costs in Estonia are so low that our system would not be cost-effective here" (interview, April 2004).

Both Bluemoon Interactive and Curonia Research appear to have assumed a passive and subservient role in their own industrial processes, and seem almost indifferent to the consequences of their productivity. The social advantages of technologies developed in Estonia are not necessarily experienced by that country's citizens; and where its citizens do benefit from such technological developments, such benefits (as this paper will stress in terms of electronic governance) may be limited to its more socio-economically privileged classes. Indeed, as the Russian cyber-attacks upon Estonian state and commercial websites in May 2007 demonstrated, Estonia's

\footnotetext{
5 "These figures on online banking and tax returns were published (respectively) by the Online Banking Review in October/November 2003 and by the Estonian Tax Board in April 2003. Available at: http://obr.bankingreview.com.au/default.aspx?iid=1559\&startpage=page0000012, last accessed 14th April 2009; and http://www.epractice.eu/en/news/284094, last accessed 14th April 2009."
} 
economic emphasis on new media technologies may also open the country to modes of risk unforeseen by its techno-economic pioneers - not only in terms of its own sociopolitical structure but also in terms of its national security. The fact that Russia's diplomatic hostility towards Estonia relates primarily to the Baltic state's treatment of its own Russian-speaking minority (a sector of the population increasingly disempowered and disenfranchised by imbalances in uses of, and access to, new media technologies) suggests that issues of demographic integrity and national security may be related to those technologies both in terms of probable cause and possible outcome.

\section{Electronic infrastructure}

Estonia's IT advances have inspired a certain amount of journalistic and academic hype. In 2004 The Guardian's Ben Aris described Estonia as "the most intensely wired country in the world." At the end of April 2005, the Economist Intelligence Unit's sixth annual ranking of the "e-readiness" of 65 different countries - in which Denmark, the United States and Sweden took the top three spots - placed Estonia at number 26, just ahead of fellow new EU member Slovenia. At the same time, Denis McCauley, the Director of Global Technology Research at the Economist Intelligence Unit, predicted that Estonia "would continue to make gains based on the amount of private and public funding going into [its] Internet development" (Pruitt 2005).

According to the International Telecommunication Union, Estonia reported 33 per cent of its population as Internet users in 2003 - a figure two per cent higher than Ireland's (Fuller 2004). That same year, TNS Emor pollsters reported that as many as 45 per cent of Estonian residents aged 15 to 74, or around 576,000 people, used the Internet, and that this figure had risen by 59,000 since the previous year. More recently, Ernsdorff and Berbec (2007: 174) have reported that " 52 per cent of the Estonian population uses the Internet, [and] 35 per cent have their own computer at home."

In July 2004, Public Sector Technology and Management reported that Estonia had spent about one per cent of its state budget on public sector IT development over the previous ten years. As a result of this low level of public investment (relative to the economic benefits gained from the nation's digital infrastructure), much of the responsibility for e-development - both infrastructurally and educationally - has devolved to the private and voluntary sectors.

One prominent example of this phenomenon can be seen in the field of wireless Internet service provision. In 2000 the country had three 'wi-fi' areas. By 2004 it had 340. The campaign to spread wireless Internet coverage across Estonia was spearheaded by a self-employed volunteer called Veljo Haamer. Haamer's project received some funding from private companies and local governments, particularly in rural areas where wireless coverage is seen as an inexpensive way to increase Internet access, but no direct financial support from central government. This may in part reflect prevalent laissez-faire positions which have discouraged post-independence Estonian administrations from all but the most urgent (or cosmetic) economic interventions in the development of the country's social infrastructure, preferring to allow the commercial and voluntary sectors to satisfy demand for such services. Indeed, despite his project's success, Haamer does not see IT development on its own as a panacea for his country's social problems. He comments: "Technology itself doesn't solve problems. Technology is only a tool, not a solution" (interview, July 2004).

Some of the most impressive results of Estonian e-development can be witnessed in the Look@World project. Between 2002 and 2004 this educational programme trained 102,697 people (around eight per cent of the population) in basic Internet and computing skills. The project was funded by contributions from the private sector, most significantly from a banking industry keen to shift its clients online - and 
therefore to reduce the costs associated with the maintenance of traditional high street branches (and perhaps unconcerned by the lack of Internet access available to financially disadvantaged sections of the population).

In recent years, however, government interest in this programme has diminished. The Chairman of the Look@World project Alar Ehandi has lamented the Estonian government's failure to support the programme. Ehandi has commented: "When we started, the Prime Minister was Mart Laar. He did a lot to support us. The current government is very much in favour of the information society - in words - but they don't do so much. There are more people who want training. The private sector has invested nearly 3,000,000 euros. Now it's the government's turn" (interview, July 2004).

An energetic free-marketeer and IT enthusiast, Mart Laar served as Prime Minister of Estonia from 1992 to 1994, and from 1999 to 2001. Despite Laar's dynamism, subsequent coalition administrations have lacked the political will or economic wherewithal to continue to implement Laar's ambitious programmes of technological development. This problem has been echoed by Tex Vertmann, who served as Communications Adviser to four Estonian Prime Ministers - Mart Laar, Siim Kallas, Juhan Parts and Andrus Ansip. Vertmann comments: "Mr Laar was enthusiastic about eservices, e-democracy and e-society. Mr Kallas and Mr Parts were more focused on developing knowledge-based society than on the e-thing" (interview, July 2004).

\section{Electronic government}

In 2002, in cooperation with the United Nations Development Programme, the Soros Foundation and the Open Society Institute, Estonia established a non-profit organisation called the E-Government Academy. In an interview with $B B C$ News, Ants Sild, a programme manager at the E-Government Academy, said: "What we mostly teach... is understanding what your goals are as a government, and then figuring out how technology can help you achieve those goals" (Boyd 2004).

One is forced to wonder in this connection whether an independent organisation should in any way be defining the goals of government, and for that matter whether the goals of government are always necessarily consistent with the interests of its electorate; and one is again reminded of Bynum and Rogerson's fear that "dictatorial governments might find ways to use computer technology to control... the population more effectively than ever before" (Bynum and Rogerson 2004a: 6).

In 2002, the TNS survey of 'Government Online' reported that 21 per cent of Estonians transacted government-related business online, one per cent below the Swedes, and one per cent above the Finns and the Danes. Two years later, the Economist Intelligence Unit named Estonia, Slovenia and the Czech Republic as the leaders in egovernment of the new EU member states: "Although held back by connectivity problems, these countries have gone well beyond e-government window-dressing, and compare favourably in many areas with the rest of the EU, particularly in shifting public service delivery online" (Pruitt 2004). However, the Economist Intelligence Unit's report also warned that Estonia's fixed-line penetration rate stood at only 46 per cent, while its broadband penetration was a mere three per cent.

In 2004 a ranking of the global development of e-government published by researchers at Harvard University placed Estonia in fifth place (Boyd 2004). The European Commission's fifth annual survey of online government services in Europe, released in March 2005, showed that, while most of the European Union's then ten newest member states scored in the lower half of the table - with average levels of egovernment equivalent to those enjoyed by the EU's older member states in 2003 Estonia alone of the new members appeared in the upper half (European Commission 2005). Indeed, according to Ernsdorff and Berbec (2007: 171), "Estonia stands as the e- 
government leader in Central and Eastern Europe and as third in the world in egovernment systems."

The Estonian government now boasts the introduction of paperless cabinet meetings and claims that this measure has saved 100,0000 U.S. dollars a year in photocopying costs alone (in addition to a 200,000-dollar annual saving made by inter-ministerial memoranda going exclusively online). The government has also announced that their paperless condition has been responsible for reducing cabinet sessions (which had formerly lasted for up to 12 hours) down to a more manageable average of 45 minutes - or even, in one case, down to 14 minutes. As the government proudly proclaims these figures, one might however ask to what extent a quarter-hour cabinet meeting fosters the processes of mature democracy, administrative accountablity and detailed debate which one might expect from the heart of a modern European government.

Since 1 January 2007, this craze for paperlessness has also come to encompass the publication of legislation. From that date the official government organ ceased its print publication (save for five paper copies) and now exists in an almost exclusively electronic form. For Marshall McLuhan the adoption of the alphabet by European cultures allowed for a sudden and massive expansion of public literacy; the resultingly literate civilisation afforded a structure in which all individuals had direct access to and therefore were equal before - "a written code of law" (McLuhan 2001: 91). Estonia's decision to consign legislative and governmental records to a domain to which a third of the population lacks access might be seen as reversing McLuhan's politically progressive process. A system in which access to legislation requires degrees of technological expertise and facilities that are not available to the entire population appears no longer to meet McLuhan's basic conditions for modern civil society.

Another of the more obviously controversial aspects of Estonia's adventures in virtual administration was established in 2001 as the flagship project of its system of egovernment. Täna Otsustan Mina ('Today I Decide') - or 'TOM' - was a website on which Estonian citizens could present proposals for legislation. If a proposal received sufficient support, it was to be discussed by the government. Although the portal boasted some 7,000 registered users, there were within a few years of its launch only 10 or 20 active members.

The TOM portal prompted a number of minor changes in Estonian legislation and governance. One of these was a proposal to put the clocks forward in the spring and back in the autumn. Another was an amendment to the law on the possession of dangerous weapons - an exemption which permitted students of Tartu University (the country's oldest and most prestigious seat of learning) to carry swords on ceremonial occasions. It is notable that the first of these was enacted in order to bring Estonia into line with the time zone of its richer northern neighbour, Finland, a nation to whose prosperity Tallinn's middle classes self-consciously aspire. It may be seen not only as reflecting a concern of the country's economically advantaged cosmopolitans and internationalists, but also in the specific interests of the commercial enterprises in north-western Estonia which do much business with the Finns. Furthermore, it virtually goes without saying that a focus upon the ceremonial sword-carrying rights of students at the country's elite university hardly provided evidence for this portal's stated intention to provide top-level governmental access for the Estonian people en masse.

According to Ernsdorrf and Berbec (2007: 176), "the TOM portal was a success at its launch in July 2001 when 359 proposals were forwarded up to the end of that year; this enthusiasm was however not maintained and this is reflected by only 49 proposals being submitted in 2005." In fact, the website was generally considered an object of national ridicule, embarrassment or indifference. Mart Parve, technology correspondent for Estonia's most popular daily newspaper, Postimees, has called the initiative farcical, and has characterized its regular users as "freaks and geeks". Parve 
continues: "Some famous freaks are trying to start new laws, but it's not working. We've been quite pessimistic about the state since Soviet times. E-government is not employed at the level it should be. We're very interested in new technologies, but we don't use them properly" (interview, July 2004).

As Ernsdorff and Berbec (2007: 177) report, Estonia's TOM website found itself sidelined and a new portal is now tacitly acknowledged by the country's political elite as the primary arena for the proposal and discussion of legislation. This website is run by an independent body, the Estonian Law Centre Foundation. Public opinion and legislative influence are now mediated neither by parliament nor even by a public or publicly accountable organisation. Estonia appears to be leading the way in this new Europe: the laissez-faire diminution of the public sector is balanced by the increasing domination of the private.

On 4 June 2008, the Estonian government launched the Osalusveeb (Participation Web) as its successor to the TOM portal. According to the government's own website, this site will offer a chance for "everyone [to] make suggestions to the state for simplifying public services". With such an agenda set in advance, it seems unlikely that this site will offer significant opportunities for the Estonian people to formulate policy alternatives to the principles of public sector downsizing so essential to the permissive market economics of its centre right administrations. This new forum for debate appears to be telling the Estonian electorate that their civil duty (and the extent of their democratic privilege) is to devise policy details appropriate to the government's own political programme.

\section{Electronic democracy}

In May 2005 the Estonian parliament passed legislation to introduce online voting at the country's local elections that October. According to The Baltic Times newspaper (11 May 2005): "Estonia would become the only country in the world where people could vote through the Internet from home. Although online voting is widespread in other countries, a voter must conduct his E-vote at a polling station computer." On 12 May 2005, the Associated Press added: "Voters will need an electronic ID card, an ID-card reader and internet access... It is estimated that nearly 1 million of Estonia's 1.4 million residents already have an official electronic ID card. The ID cards, launched in 2002, include small microchips and offer secure e-signing through a reader attached to their computers."

According to Aleksei Gunter, a leading journalist at the Estonian newspaper Postimees, "at the 2005 local elections, most of the e-votes went to the Reform Party. That was somewhat predictable, because the young and the well-off, who obviously have the means and the interest to use new technologies, favour that party" (interview, January 2007). In fact, according to the government's own report on that exercise in edemocracy, "the Reform Party handed out ID card readers during their election campaign" (Madise et al. 2006: 41). The report of the Estonian National Electoral Committee (2007) shows that nearly 35 per cent of the electronic vote went to the Reform Party - significantly higher than the 28 per cent which it achieved in the total vote. As Ernsdorff and Berbec (2007: 178) report, "some political parties considered evoting an opportunity to increase their support, while others conceived it a threat." Indeed, the (then) President of Estonia, Arnold Rüütel, attempted to veto the legislation which permitted online voting, on the grounds of its inherently inequitable nature and its openness to fraudulent manipulation, but was eventually overruled by the Supreme Court.

On 28 February 2007, Estonia extended e-voting to its national parliamentary elections. On 1 March 2007, the BBC News website announced that "Estonia has become the first country to use internet voting in parliamentary elections." On 7 March 2007 The Baltic 
Times newspaper added: "In what was hailed as the world's first full-scale internet election, a total of 30,243 voters chose to log their votes online" (Alas 2007a). The total number of votes cast at the election was 550,213 and the total number of eligible voters circa 940,000.

Ernsdorff and Berbec (2007: 171) have written that Estonia "is setting an example in edemocracy throughout the European Union, being the first country in the world to enable all its citizens to vote over the Internet in political elections." One might, however, call into question Ernsdorff and Berbec's use of the word 'all': although a majority (but certainly not all) of its citizens have Internet access, a much smaller proportion enjoy home access to the technology required to vote online.

It has been estimated that nearly two-thirds of Estonians currently use the Internet, although only about half of those have web access in their own homes. These people represent, for the most part, the country's educated urban middle class. The implementation of online voting has meant that this sector of the population (i.e. those who tend to be supporters of the centre right coalitions that invariably govern Estonia) will find it easier to exercise their democratic rights than those on the other side of the digital divide.

Voter mobilisation is, of course, a key factor in the winning of elections. Oberholzer-Gee and Waldfogel (2005: 74) write that "recent voting studies emphasise the importance of voter mobilisation by political candidates." Trost and Grossmann (2005: 128) add that "you need to... mobilise [voters] to turn out on Election Day." In facilitating the voting process for their typical supporters, Estonia's centre right parties are therefore afforded an obvious electoral advantage by this mode of electronic democracy. This is a hypothesis with which even the former Communications Adviser to the Prime Minister, Tex Vertmann, has "theoretically" agreed (interview, July 2004). Ülle Madise (2007), Director of Audit of Estonia's State Audit Office, has claimed that online voting offers "no advantage for e-voters" - but, if that were indeed the case, one wonders why the state would bother with the trouble and expense of it at all. As Trechsel (2007: 37) points out, nearly 86 per cent of Estonians who chose to vote online did so because they found it more convenient than by traditional methods.

In an otherwise remarkably optimistic essay, Ernsdorff and Berbec (2007: 178) admit that "e-voting has never been the result of popular demand but rather a result of the imposition of yet another initiative by a young Estonian political elite." This is a position with which Jaak Aab, Estonia's Social Affairs Minister at the time of Estonia's first experiments in electronic democracy, would strongly disagree. Aab, who held his ministerial portfolio from April 2005 to April 2007, comments (interview, January 2007):

\footnotetext{
I believe that online voting encourages people to take an active part in democracy, because it gives an additional possibility to vote. It is especially important for people who cannot or have lower motivation to go to vote to the designated voting place. I am not concerned that it may primarily encourage participation among the educated middle classes, because Estonia doesn't have a big gap in Internet use, as lots of other European countries do. Research shows that in spring 2006, 60 per cent of Estonians (aged six to 74) were using the Internet. The Estonian government's aim is to provide the Internet to all Estonian people.
}

However, there appear to be several problems with Aab's argument. His first assertion that online voting promotes democratic participation - seems to contradict the evidence of various empirical studies. Gibson et al. (2004: 3) cite, for example, Scheufele and Nisbet's 2002 survey, in which "none of the modes of Internet use... was found to have any significant effect on individuals' proclivity to engage in politics."

Aab's dismissal of the education gap and the technological divide as irrelevant to Estonia is extraordinary, not only in the light of the country's massive socio-economic divisions, but also because it specifically contradicts the findings of his government's 
own report on the 2005 elections: "there were more people with high education... among actual e-voters" (Madise et al. 2006: 30). Breuer and Trechsel's Report for the Council of Europe (2006: section 7) on the 2005 elections meanwhile found that "evoting in Estonia is not as seducing for elderly people as it is for younger generations"; that "language remains a problem in a linguistically divided society" (minority Russianspeakers are less likely to use the system than majority Estonian-speakers); and that "computing knowledge remains a hurdle for e-voting." Although Breuer and Trechsel reject general educational status as a particular factor in citizens' proclivities towards online voting, the specific case of IT-education (which is of course related to the quality and currency of general education) is seen in this context as a crucial - and therefore divisive - issue. Indeed, Trechsel's Report for the Council of Europe on the 2007 election goes on to note that "the share of highly educated voters was almost 20 percentage points higher among e-voters than among traditional voters" (Trechsel 2007: 43). Trechsel's 2007 report also stresses that, in terms of economic status, "the highestincome category is heavily overrepresented among e-voters" and that "a very large part of the Russian speaking community [refrained] from using this tool" (Trechsel 2007: 44). Trechsel's study demonstrates that more than 62 per cent of voters who elected not to vote online did so because they lacked the necessary facilities (Trechsel 2007: 38). It also points out that "e-voters do not only differ [from traditional voters] with regard to their socio-demographic and economic profiles, but they also do so... with regard to their political preferences" (Trechsel 2007: 49).

To the extent that socio-economic status can be elaborated upon geographical lines, it seems significant that, with the exception of the university city of Tartu, the areas of Estonia which, according to the report of the Estonian National Electoral Committee (2007), demonstrated the highest use of electronic voting among the national turnout were Tallinn itself and its neighbouring counties in the affluent north-west of the country. With barely more than a third of Tallinn's score, the economically depressed county of Ida-Viru on Estonia's eastern border with Russia showed the lowest rate of adoption of the electronic system.

Further to these concerns as to the equity of the electronic voting system, the Organisation for Security and Co-operation in Europe's report from the year 2007 also highlighted the lack of "oversight of the Internet voting process by political parties or civil society" and went so far as to question "whether [in future] the Internet should be available as a voting method, or alternatively whether it should be used only on a limited basis or not at all" (OSCE 2007: 2). This lack of enthusiasm has not, however, prevented Estonia from forging ahead with plans to introduce voting from mobile telephones in time for its municipal elections in 2009 (Alas 2007b). It is perhaps notable, however, that its fellow Baltic nation Lithuania has recently rejected proposals for online elections (Vaiga 2008).

According to the recommendation on Legal, Operational and Technical Standards for EVoting adopted by the Committee of Ministers of the Council of Europe on 30 September 2004, "measures shall be taken to ensure that the relevant software and services can be used by all voters" (Council of Europe 2005: 15). When Jaak Aab suggests that his government intends (one day) to provide full Internet access to their entire electorate, one might therefore ask whether online voting should be implemented before that day has come. Indeed, that day seems further off than Aab implies: although he suggests that 60 per cent of his compatriots have Internet access, he neglects to mention that, for the vast majority, this access does not include the cardreader necessary for online voting. As Ernsdorff and Berbec (2007: 180) emphasise, "one prerequisite for popular e-voting had certainly not been satisfied, namely that of the spreading of specific electronic ID card readers... They are not common for personal use and furthermore, they are expensive."

According to the website of the $22^{\text {nd }}$ Chaos Communication Congress, Tarvi Martens was "the guy who made e-voting possible for the whole nation first time in the 
history".6 From 1993 to 1997 Martens headed Estonia's Data Communication Department, where he championed the introduction of a national electronic identity card. Martens then moved to Sertifitseerimiskeskus (SK), the private company responsible for national identity cards, electronic signature systems and card-readers. Since 2003, Martens has worked with the National Electoral Committee to implement an online voting system. He is Chief Operations Officer of SK and the Project Manager for the Estonian e-voting system. Martens comments that "the increasing number of evoters is of course encouraging. I see two main factors behind it: (a) an increasing awareness of ID-card electronic usage, and (b) a steady, trustworthy and transparent evoting system which produces increasing confidence in users" (interview, March 2007).

Despite Martens's confidence in the system, he has admitted that "we do not possess exact data about number of card-readers installed among ID-card holders" (interview, March 2007). This tallies with the official Estonian government report on Internet Voting at the Elections of Local Government Councils on October 2005 (Madise et al. 2006: 8) which reveals that "there is... no reliable data on the distribution of card-readers in Estonia."

However, Martens's Marketing Manager at SK, Andres Aarma, has been able to provide rather more detail on the subject. Aarma comments: "Our estimate for the total number of readers installed is currently around 70,000-80,000. How many of those are in personal use and how many in organisational use we do not know. In the end of 2006 we concluded an agreement with OMNIKEY which won the international tenders for procurement of up to 600,000 readers between 2007 and 2009.7 The aim is to enable everyone affordable access to the key public infrastructure" (interview, January 2007).

It may therefore be understood that Estonia initiated an online voting system at a time when nobody knew how many people had access to the technology which would allow them to vote from home - although it was probably not many more than the 3.2 per cent of the electorate who actually used the system. But at least the private company which recommended the system in the first place has now secured a deal to sell the technology necessary to make it work. In this context, there is perhaps something chilling about the final words of a presentation given by Tarvi Martens (2007) on Estonian e-voting: "There's no way back."

\section{Conclusions}

Where then might this case study lead us? Certainly (obviously) not towards the undilutedly cyberoptimistic perspective. The Estonian example demonstrates, if nothing else, that technological developments do not necessarily result in greater levels of participatory citizenship, democratic accountability or social justice. The empirical evidence presented in this study suggests that the good intentions of many of the country's new media professionals and techno-enthusiast civil servants and politicians may be undermined both by the influence of commercial interests and (more so) by the failure of some of those (though by no means all of those) electronic visionaries to see that, rather than solving the country's social problems, the imposition of new technologies upon relatively youthful processes of government and democracy may in fact exacerbate those problems.

It is perhaps worth noting that the interviews conducted for this study suggest that those cyber-crusaders least influenced by commercial or political concerns - such as the journalists, academics and voluntary workers - seem rather more sceptical than the

\footnotetext{
${ }^{6}$ Available at: http://events.ccc.de/congress/2005/fahrplan/speakers/866.de.html, last accessed 20 april 2009.

${ }^{7}$ OMNIKEY is a German-based company supplying hardware for electronic information and communication technologies.
} 
bankers, industrialists, civil servants and politicians as to the revolutionary social potential of the country's development of (and dependence upon) new media technologies. In fact, even the founding father of the Estonia's Tiger Leap Initiative, Linnar Viik, has expressed doubt over these experiments in electronic democracy. In 1997 Viik returned to Estonia from his studies in Finland bursting with ideas to promote his country's electronic development, and became the government adviser who changed the face of Tallinn's economy. More recently, however, Viik has commented (interview, July 2004): "E-democracy doesn't have a real impact on the democratic process. Democracy in Estonia is like a small child. I can compare it to my five-year-old son. He can talk, he knows some manners, he knows how to pee - but he's still learning. This technology is just a tool for teaching and learning and expressing yourself."

Viik, who currently serves as an associate professor at the Estonian IT College in Tallinn, believes that traditional modes of parliamentary democracy are now obsolete: "I don't so much believe in representative democracy. I believe in participatory democracy" (interview, July 2004). Viik's acknowledgement of the public distrust of traditional political structures and processes reflects a prevalent (and convincing) perspective within contemporary political studies; and many scholars, including Coleman and Spiller (2003), have argued that new media technologies have a crucial (though neither exclusive nor uncontroversial) role to play in any strategy which hopes to restore public trust and participation in democratic processes. However, for as long as such participation remains limited by educational, demographic and socio-economic conditions, this mode of democracy will continue to be dogged by the concern that it has become the willing instrument of entrenched power structures and privileged interest groups.

In January 2003 Donald Rumsfeld famously suggested that the post-Communist nations of central and eastern Europe epitomised what he called the "New Europe". If indeed they do represent the latest stage of European development, then perhaps the ways in which Estonia, ostensibly the most progressive of these eastern European states, has adopted and adapted these new media and communications technologies may also reveal something of the economic and political future of the European Union itself. Whether this future is revealed as a techno-utopia or a cyber-dystopia remains, of course, to be seen. What this particular study might finally suggest is that neither perspective is entirely convincing - and that in order to move as best we can towards the former state we must remain constantly aware of the dangers of the latter position - that, rather than optimism or pessimism, a continuing critical scepticism might best inform the ways in which we negotiate our progress towards a more relevant and effective mode of participatory democracy.

\section{Bibliography}

Alas, J. (2007a). 'Card readers the only challenge in e-election', The Baltic Times, 7 March 2007.

Alas, J. (2007b). 'Thumbs up for mobile voting', The Baltic Times, 3 October 2007.

Aris, B. (2004). 'Technological Tiger', The Guardian, 22 April 2004.

Associated Press (2005). 'Estonia will try Internet elections', 12 May 2005.

Åström, J. (2004). 'Digital democracy', in R. Gibson, A. Römmele and S. Ward (eds), Electronic Democracy. Abingdon: Routledge. pp.96-115.

Baltic Times (2005). 'Online voting raises concern, gives new coalition first challenge', 5 May 2005.

$B B C$ News (2007). 'Estonia claims new e-voting first', 1 March 2007.

Boyd, Clark (2004). 'Estonia opens politics to the web', BBC News, 7 May 2004. 
Breuer, F. and Trechsel, A. (2006). Report for the Council of Europe: E-Voting in the 2005 local elections in Estonia. Strasbourg: Council of Europe.

Bynum, T.W. and Rogerson, S. (2004a). 'Ethics in the Information Age', in T.W. Bynum and S. Rogerson (eds), Computer Ethics and Professional Responsibility, Oxford: Blackwell Publishing. pp.1-13.

Bynum, T.W. and Rogerson, S. (2004b). 'Global Information Ethics', in T.W. Bynum and S. Rogerson (eds), Computer Ethics and Professional Responsibility, Oxford: Blackwell Publishing. pp.316-318.

Castells, M. (1996). The Rise of Network Society. Oxford: Blackwell Publishing.

Coleman, S. and Spiller, J. (2003). 'Exploring New Media Effects on Representative Democracy', The Journal of Legislative Studies 9 (3), pp.1-16

Coleman, S. (2005a). 'E-democracy - what's the big idea?'. Manchester: British Council Governance Team.

Coleman, S. (2005b). 'Just how risky is online voting?', Information Polity 10, pp.95-104.

Coleman, S. (2005c). 'The Lonely Citizen: Indirect Representation in an Age of Networks', Political Communication 22 (2), pp.197-214.

Collier, M. (2007). 'Estonia breaks into globalisation top 10', The Baltic Times, 23 October 2007.

Council of Europe (2005). Legal, Operational and Technical Standards for E-Voting. Strasbourg: Council of Europe.

Ernsdorff, M. and Berbec, A. (2007). 'Estonia: The short road to e-government and edemocracy', in P. Nixon and V. Koutrakou (eds), E-government in Europe. Abingdon: Routledge. pp.171-183.

Estonian National Electoral Committee (2007). Parliamentary elections 2007: Statistics of e-voting. Tallinn: Estonian National Electoral Committee.

European Commission (2005). Online government is now a reality almost everywhere in the EU. Brussels: European Commission, 8 March 2005.

Fuller, T. (2004). 'In Estonia, E-banking, E-commerce, E-government', International Herald Tribune, 13 September 2004.

Gibson, R., Lusoli, W., Römmele, A. and Ward, S. (2004). 'Representative democracy and the Internet', in R. Gibson, A. Römmele and S. Ward (eds), Electronic Democracy. Abingdon: Routledge. pp.1-16.

Kaplan, R. (2001). Warrior Politics. New York: Vintage Books.

McLuhan, M. (2001). Understanding Media. London: Routledge.

Madise, Ü., Vinkel, P. and Maaten, E. (2006). Internet Voting at the Elections of Local Government Councils on October 2005. Tallinn: Estonian National Electoral Committee.

Madise, Ü. (2007). Internet Voting in Estonia Free and Fair Elections. Tallinn: Estonian National Electoral Committee.

Margolis, M. (2007). 'E-government and democratic politics', in P. Nixon and V. Koutrakou (eds), E-government in Europe. Abingdon: Routledge. pp.1-18.

Martens, T. (2007). Internet Voting in Practice. Tallinn: Estonian National Electoral Committee.

Middleton, C. (1999). 'Ethics Man', Business and Technology, January 1999, pp. 22-27.

Mikecz, R. (2005). 'Ambition versus Pragmatism', in A. Charles (ed), EU Enlargement - One Year On. Tallinn: Audentes University. pp.146-156.

Needham, C. (2004). 'The citizen as consumer: e-government in the United Kingdom and the United States', in R. Gibson, A. Römmele and S. Ward (eds), Electronic Democracy. Abingdon: Routledge. pp.43-69.

Neumann, P. (2004). 'Computer Security and Human Values', in T.W. Bynum and S. Rogerson (eds), Computer Ethics and Professional Responsibility. Oxford: Blackwell Publishing. pp.208-226.

Nixon, P. (2007). 'Ctrl, Alt, Delete: Rebooting the European Union via e-government', in P. Nixon and V. Koutrakou (eds), E-government in Europe. Abingdon: Routledge. pp.19-32.

Nixon, P. and Koutrakou, V. (2007). 'Introduction', in P. Nixon and V. Koutrakou (eds), Egovernment in Europe. Abingdon: Routledge. pp.xviii-xxviii. 
Oberholzer-Gee, F. and Waldfogel, J. (2005). 'Strength in Numbers: Group Size and Political Mobilisation', Journal of Law and Economics 158, pp.73-91.

OSCE (2007). Republic of Estonia Parliamentary Elections 4 March 2007. Warsaw: OSCE / Office for Democratic Institutions and Human Rights.

Pleace, N. (2007). 'E-government and the United Kingdom', in P. Nixon and V. Koutrakou (eds), E-government in Europe. Abingdon: Routledge. pp.61-74.

Pratchett, L. (2007). 'Local e-democracy in Europe: democratic x-ray as the basis for comparative analysis'. Paper presented at the International Conference on Direct Democracy in Latin America, Buenos Aires, 14-15 March 2007.

Pruitt, S. (2004). 'Poor infrastructure hinders E-government in new EU', Network World Fusion, 1 October 2004.

Pruitt, S. (2005). 'Europe makes greatest gains in E-readiness', IDG News Service, 20 April 2005.

Raab, C. and Bellamy, C.. 'Electronic democracy and the "mixed polity"', in R. Gibson, A. Römmele and S. Ward (eds), Electronic Democracy. Abingdon: Routledge. pp.1742.

Trechsel, A. (2007). Report for the Council of Europe: Internet voting in the March 2007 Parliamentary Elections in Estonia. Strasbourg: Council of Europe.

Trost, C. and Grossmann, M. (2005). Win the Right Way. Berkeley: Public Policy Press.

Tubalkain-Trell, M. (2008). 'Report calls out underachieving minister', in The Baltic Times, 9 July 2008.

United Nations World Public Sector Report (2003). E-Government at the Crossroads. New York: United Nations.

Vaiga, L. (2008). 'Lithuania says "no" to E-voting', in The Baltic Times, 23 January 2008.

Xenakis, A. and Macintosh, A. (2007). 'A methodology for the redesign of the electoral process to an e-electoral process', International Journal Electronic Governance 1 (1), pp.4-16 